\title{
ARTICLES
}

\section{A Little to One Side \\ Caregiving, Spatial Seclusion, and Spiritual Border-Crossing in Frail Old Age among the Tuareg (Kel Tamajaq)}

\author{
Susan Rasmussen \\ Department of Anthropology and Comparative \\ Cultural Studies \\ University of Houston
}

\begin{abstract}
This essay examines the meanings of the seclusion of frail elders and the roles of small children who act as their primary caregivers in rural Tuareg communities of northern Niger, and explores the implications of these arrangements for intergenerational relationships. Data suggests that both cosmological and socioeconomic forces shape the seclusion and caregiving of frail elders. It is argued that, despite some physical decline and social withdrawal in these circumstances, particularly on approaching death, nonetheless there is enhanced spiritual power in which these elders and their small caregivers cross thresholds toward new sources of meaning. More broadly, the essay contributes to debates over the meanings of disengagement over the life course and the semiotics of peripheral and secluded spaces.
\end{abstract}

Keywords: aging and the life course, religion, symbolism, disengagement theory, household cycle, Africa

\section{PERIPHERAL SPACES AND FraIl Elders} Abjection or Liminality? The Problem of Spatial Seclusion, Caregiving, and Boundaries among the "Old/Old"

In Tamajaq-speaking communities of semi-nomadic, Muslim, traditionally-stratified Tuareg, sometimes called Kel Tamajaq, (after their Amazigh language) of Niger and Mali, many frail elders are lodged separately: outside or adjacent to the household compounds of their married adult children. Their primary visitors and caregivers are small children, who bring them food cooked by the adults. They are rarely mistreated or neglected. Yet most persons of advanced age do appear to experience, on the surface, some social, spatial, and political marginalization in their seclusion. On closer scrutiny, however, there emerge more complex meanings to their predicament, explored in this essay.

The seclusion of young women has received considerable attention in anthropological studies of gender. Less understood is the seclusion of "old/old" persons in aging studies. It is now recognized that age and aging, like gender and sexuality, are culturally constructed, rather than essential categories and experiences, (Cohen 1998; Lamb 2000; Rasmussen 1997; Sokolovsky 2009). This essay examines the expression of aging constructions through residential spaces where frail elders are cared for, how they are cared for in these spaces, and their relationship to their often-primary caregivers - young children usually their grandchildren. Fundamental to understanding the patterns of caregiving and the meanings of seclusion of frail "old/old" persons in Tuareg society, I argue, are intergenerational relationships and spiritual and economic forces, both longstanding and emergent. Longitudinal data from my field research reveal some disengagement, even reversal, of roles of frail elderly physically and economically (Cumming and Henry 1961; Gutmann 1987), but also their active engagement spiritually.

The goal here is to detach frail elderhood from its 
exclusively passive, "deficiency model" connotations. Another goal is to offer critical refinements of disengagement and "old/" old concepts in anthropology of aging. More broadly, the analysis links the semiotics of space and social practice to age and intergenerational relationships.

\section{Historical and Ethnographic Overview}

In cultural terms, Tuareg communities display both unity and diversity (Bernus 1981). Today, most are semi-nomadic, and reside in rural, semi-sedentarized, agro-pastoral oases and small towns in the Saharan and Sahelian regions of Niger, Mali, Burkina Faso, Libya, and Algeria. ${ }^{1}$ Relations between the pre-colonial stratified social categories of nobles, tributaries, smith/artisans, and former slaves are much modified, and are breaking down in the towns (Bouman 2003; Claudot-Hawad 1993; Nicolaisen 1997). ${ }^{2}$ Occupations - of combined livestock herding, oasis gardening, Islamic scholarship, artisanry, caravanning and other itinerant trading, and labor migration-are no longer based strictly upon descent or social stratum affiliation. There is much social interaction between the sexes, and most women enjoy high prestige and independent property ownership. ${ }^{3}$

Regional confederations and smaller descent groups and clans are headed by traditional leaders whose powers were modified first by French colonial and later independent nation-state administrations. Most Tuareg groups now tend toward bilateral succession, inheritance, and descent, with varying degrees of matrilineal influences pre-dating central state and Qur' anic-sponsored patrilineal property laws, rituals, and mythico-histories. ${ }^{4}$ Brothersister relationships remain strong, frequently enduring beyond spousal relationships into late life. Ideally sisters, daughters, and mothers reside near each other, but now some follow husbands to the latters' distant work sites. Most property is controlled by elders through gradual preinheritance gifts and endowments. There are threats from recurrent droughts, locust invasions, and armed conflicts between Tuareg separatist dissident rebels and the central state governments of Niger and Mali (Bourgeot 1994; Boilley 1999; Dayak 1992; Keenan 2003; Oxby 1990). ${ }^{5}$

These wider forces have not completely obliterated longstanding property arrangements, social relations, or communal local ritual roles, but have prompted their creative negotiations and modifications. Many widelyheld ideals in caregiving still suggest a poetic cosmology of intergenerational complementarity and continuity, and these ideals persist in much practice.

\section{Home Alone: A Closer LoOK}

\section{The Perspective of Sidi (Pseudonym): From Hidden Space and Muted Voice to Active Engagement}

Upon my return to a rural community of my long-term research in northern Niger, I noticed that an elder, whom I shall call Sidi, the aged father of a research assistant in my host family, was now much more enfeebled, perhaps terminally ill. He occupied a one-room, adobe mud building formerly used as a guest bedroom in the cold dry season and for storage in the hot season, when tents or the open were used for sleeping. This now-dilapidated small building was located in the now-deserted compound that had once been home to Sidi's extended household. I, too, had stayed there as the family's guest on other visits in the past. But now that compound was abandoned; there were no more tents of married women inside it (though several of his daughters resided nearby). The roofs of a few remaining empty adobe houses had caved in. The central courtyard had become overgrown with weeds, discouraging entry. A broken tin door had been erected in a gap on one side of the back mud wall-perhaps from fear the elderly occupant might wander off, and/or harm himself. Yet few adults made prolonged visits. His married daughters in neighboring compounds cooked his food and occasionally looked in on him. His young grandchildren almost always took the dishes to him, and spent far more time with him than his adult children.

During my visit, Sidi recognized me, warmly taking my hand, but he sat rather dejectedly upon his mat inside the crumbling edifice of what had once been a well-maintained grass building used for guests (imagaren-also a term for newborn babies, strangers, and foreigners, such as myself). Was Sidi now in some way a "guest," "stranger," and/or "foreigner?"

The physical facts of fragility and illness are undoubtedly significant here, and partly explain the reclusiveness of these "old/old" elders; but they do not explain entirely why they are lodged apart, secluded, and encouraged to be close to, not their grown adult children, but their small grandchildren. In Tuareg communities, persons at opposite poles of the life course-frail elders and young children-are vulnerable, yet powerful. They, not others, tend to congregate inside a frail elder's residential space. Thus there is a connection between seclusion, marginality, and thresholds across the borders of life and death. What sort, exactly? Here I show that spatial and spiritual transformations in elders' caregiving derive from both cosmological and domestic forces. There are social and 
symbolic parallels, and ritual and mythico-historical complementarity between persons of alternate but not adjacent generations.

In semi-nomadic rural communities, chronological age is difficult to ascertain precisely, due to lack of birth records (Rasmussen 1997). Many local residents define age according to not strictly biological or literal markings, but rather, according to social and ritual criteria: for example, one is defined as "old" (masc. amghar, fem. tamghart) when one's children are ready to marry or are married (Rasmussen 1997,2000). For many elders, there tends to be increasing emphasis upon participating in both Islamic and para- or pre-Islamic rituals.

There are also hints of another age category approximating the western academic category of "old/ old": many refer to persons of advanced age who are frail by a different Tamajaq term: wa wachere (fem. ta wacheret; plural, win wacharen), rather than amghar, which as noted, denotes a still-vigorous older adult with married children and also "chief" and "leader." In other words, elders who are frail and/or ill have already passed through their earlier social and ritual elder status of still-vigorous, authoritative and active parents of marriageable or married children. There is also a term in Tamajaq, takhal, approximating conventional notions of "dementia" associated with old age. This is very different from anubzug, permanently insane, which may be applied to persons of any age, who, as noted, may also become secluded at home, but whose seclusion has very different meanings from the seclusion of frail (though sane) elders (Bernus 1969; Rasmussen 2001b).

Gender constructs are also relevant here, though not the sole determinant of Sidi's predicament. In most rural communities, one can still count the number of households by counting female-owned tents: the married woman brings her tent (ehan) as dowry, which she owns, to the household upon her wedding. Elderly female relatives of the bride construct it during the week-long wedding celebration (Brett and Fentress 1997). Since tents are owned by married women, who retain them even on divorce, men can be without their own home in more nomadic communities, though in more sedentarized communities, men build and own most new adobe houses they construct next to the wife's nuptial tent. Sidi was not divorced, however, and his compound earlier had contained both his house and his (now deceased) wife's tent, a typical pattern in that semi-nomadic community. Whether more or less nomadic, very elderly (especially widowed) men and women alike often withdraw from their previous residence, and occupy separate domestic spaces. Houses are usually passed to sons. Tents are usually destroyed and the land beneath them left vacant for a year as "sacred" space (Ag Soliman 1999). Later, a marrying granddaughter's nuptial tent is constructed there.

Thus, gender constructs do not explain all meanings of frail elders' secluded space. Although aging men are more often without a tent upon widowhood or divorce, once frail, elderly women are also, often, secluded and in advanced age; both tend to move away into similar peripheral spaces.

As Lawrence Cohen (1998) observes in his study of urban Hindu Indian frail elderly persons, dying spaces are not static "things," but are contested, and interpreted from different vantage points. I agree that we need to move from third-person frames to second-person positioned and contested accounts of the "familiar body" in the firstperson construction of experience, and to the voices of old people (Cohen 1998:183). I also caution against taking too literally the surface attributes of spaces and built-forms, for example, inferring from them rigid social correlates (Goody 1958). One also cannot ignore personal emotions such as grief (Rosaldo 1991). Within these spaces, do individuals experience their own advanced aging as frail or powerful, and if powerful, in what sense?

The first-person voice is difficult to elicit here. Sidi managed to smile weakly, and greeted me warmly by my name. When I inquired how he was, he chuckled somewhat ruefully, and did not give a direct verbal reply, but gestured vaguely toward himself, and shook his head. He slept intermittently. Sidi's adult children were evasive when I asked about his welfare. Although his adult daughters continued to cook for him in their neighboring kitchens, and occasionally looked in on him directly, they did not linger, enter, or approach, but stood briefly in the door-frame, nodded a greeting, and then retreated. Notably, they did not avoid pausing in the doorframe here, in contrast to their strict practice of this taboo while holding babies. They usually sent small children instead to stay with him longer. In the presence of these children, Sidi, when not too ill, held conversations with his grandchildren on everyday work situations, the weather, and more general concerns such as local history. Thus there was a juxtaposition of living and dying in the same space.

Other fragile elders more explicitly discussed their feelings with me, recognizing themselves as "very old now...lacking strength." Several frail elders lamented that "no one takes me seriously now...I see things I do not like, 
but I can only watch." One younger adult woman (i.e., married and of childbearing age) commented, "An elder does not do work or make any decisions. When one is very old, one follows the children." Some explained that, when they want to shield an elderly person, they say he/ she is senile (takhal), even if not really the case. Dementia, in fact, is often disputed. A wife, for example, disagreed with her husband after he described an old chief to me as senile; she insisted, "No, he is not senile, only his feet are incapacitated, that is why he does not go out." As anywhere, illness and injury prevent motility.

Yet even infirmity does not fully explain frail elders' secluded, peripheral residential space, since such a space is highly formalized and involves specifically very young visitors. Why did adults of the adjacent generation shun entering this space? Persons suffering from noncontagious diseases are not usually secluded; rather, they are surrounded by close relatives and friends who try to heal them. By contrast, persons suffering from contagious infectious diseases and persons undergoing healing of spirit-related illnesses are secluded for varying time periods. What social engagement takes place in this peripheral space? Death could not be entirely polluting, since young children were permitted, indeed encouraged to enter this space.

Local definitions of fragility related to age usually merged unspecified bodily and/or mental decline, disability, and illnesses, or simply advanced senescence. Many Tuareg, for example, described the life course to me with resignation, metaphorically as "like a canopy (abarkan) that gradually loses its supports for men, from about fifty years old, for women, earlier." Others asserted that "the body bends." A few organic disabilities - whether they strike at birth, in midlife or old age-are viewed as punishment for past sins (e.g., blindness without a discernable cause), or as the manifestation of parents' breaking of sexual taboos (e.g., babies born with disabilities may have been conceived outside the nuptial tent, under the moonlight, or stolen by the Kel Essuf spirits and replaced with a changeling) (Rasmussen 2000).

Age-related "mental" decline was alluded to in specific contexts, rather than philosophical generalizations. Takhal, denoting approximately "senile," (a problematic term) is usually applied to those elderly persons who tend to lose their orientation in the desert, to forget mythico-histories, and lose conversation skills, important in local cultural values. Hence the challenge of translating illness meanings and terms across cultural settings is compounded by age. Several older persons I interviewed were pointed out to me, away from their presence, as suffering from takhal, but not Sidi and not everyone in seclusion. Most people treated the sufferers of takhal with respect to their face. When they are fragile, the old/old are ideally respected and cared for by their daughters who should cook for them, or at least make sure they are fed. No one ever described Sidi as suffering from takhal to me.

The dying space of frail, dying, but otherwise normal elders can be spatially peripheral to the household while remaining in some ways central, but not marginal. For example, in India, the knotted rope and wood frame bed are often placed near the threshold of the house, or in a courtyard. This suggests a simultaneously liminal and exemplary position of its aged occupant (Cohen 1998:182). Several brief "negative case" examples show how the Tuareg threshold (temilelt) can indeed become a place of either alterity and abjection, or, as in the present case of Sidi and many other frail elders, a place of crossroads and becoming. Another frail elder, a woman who appeared suffering from the beginnings of dementia, became much more isolated in her secluded space because of her social disaffiliation. She had disputed with her brother and female cousin over the disposal of their livestock property, and also became estranged from her nephews (brother's sons). They did not linger in the space of her tent or bring her food. She tragically became insane and tried to beat them when they approached. Another woman, though cared for, diagnosed as permanently "insane" (tanubzug), remained tied up inside a tent inside her uncle's compound. No small children brought this woman, food, eitherin fact, she allegedly seized a small kid goat and ate it whole-thereby indicating possible neglect and hunger (Rasmussen 2001b).

Thus there are distinctions within the category of "frail" elder and variable meanings of seclusion. Seclusion is qualitatively different for those who are considered antisocial or insane. Sidi's and others' residential arrangements were, therefore, more "typical" or "usual" for those elders locally defined as "normal" though frail (i.e., those with declining social and economic powers). How and why?

There is a notion, in seclusion, of some special condition, "pollution," "holiness," and/or "profane," status, or perhaps "sacredness" - concepts notoriously difficult to translate and sort out. As shown in anthropology of religion, these concepts may have both positive and negative connotations (Douglas 1966; Gottleib 2004). As Radcliffe-Brown pointed out long ago, the body of a Polynesian chief is tapou: at once holy and profane (Radcliffe-Brown 1939). The meanings of Tuareg frail 
elders' seclusion and their consequences in caregiving are different from those frequently noted in other cultural settings, for example, urban and rural India (Cohen 1998; Lamb 2000). In contrast to what Lamb reports in rural Hindu India (2000), most Tuareg do not consciously attempt to formally become ascetic renouncers in order to prepare for eventual death and/or rupture ties, or detach from the pleasures of life, even those who pursue more intensive Qu'ranic study. Nor is the Tuareg arrangement equivalent in meaning to installing a frail elderly parent in his or her own room in many middle-class US households for the purpose of individual privacy, replicated for other family members when affordable. Nor do these meanings exactly correspond to those of the US hospice. Nor is there an exact parallel to Cumming and Henry's (1961) classical disengagement theory, which argues that upon aging, there is conscious withdrawal from active participation in life in preparation for death. Certainly, the Tuareg case does approximate withdrawal in some respects. But this process is very selective, and moreover, in the partial seclusion of frail elders, there is also a new engagement in the spiritual domain of life: in between humans, the Islamic Allah, and spirits and ancestors, in between alternate and adjacent generations-as in effect, new parents of grandchildren (actual or classificatory, including nieces and nephews particularly those on the maternal side, children of sisters and daughters, referred to as "children of the stomach"). In effect, one lives with one foot in the social community and one foot in the realm of the afterlife. But how is this Tuareg case liminal and death-denying at once?

Upon advanced and frail aging, the public face of household authority over sons and sons-in-law in managing the domestic economy becomes more difficult to maintain. Frail elders who are respected come to occupy a status very similar to the sacred or "divine" kings analyzed in African ethnography in their ritual status and political succession conflicts and conundrums. In other words, Tuareg elders' declining powers must be hidden, since they are connected to the fertility of humans, herds, and crops.

On another level, frail elders and young children come to occupy symmetrical and complementary statuses in their mediating positions between the spirit and human worlds. These dimensions-socioeconomic, political, and religious - are all at play in the caregiving of frail elders. In other words, there is fragility and weakening, but also, ideally, alternative forms of empowering and connection, embodied in seclusion as a threshold and crossroads.

\section{Liminal Spaces in Aging Symbolism and theIR Practical Consequences in Caregiving}

Healthy Tuareg elders and their authority have received some ethnographic attention (Claudot-Hawad 1993; Dayak 1992; Rasmussen 1997,2000a,2000b). Frail elders have received less attention. The latters' physically fragile, often ill and dying, state alone, does not completely explain the significance of their seclusion. Many Tuareg believe that frail elders, like very young infants and possessed adults, live in or have close ties to solitude or "the wild" (essuf) and its spirits (Kel Essuf). It is tempting to posit an equivalence between these social categories based on their shared similar symbolic imagery, but in other ways, they are not equivalent, but complementary. Frail elders' adult children seldom speak to or about them directly, visit them only briefly, and never pronounce their names. Out of respect, Tuareg never mention the names of deceased ancestors. Very young children; however, can pronounce names of parents, but as they mature, adults discourage them from doing so. These practices of spatial segregation and name teknonymy suggest not just respect, but also transformation of social and spiritual personhood. There are cultural efforts to make advanced, frail old age and early childhood symmetrical by situating them on complementary spiritual border-crossings.

As important caregivers of frail Tuareg elders, small children also often tend the fire during the cold, dry sandstorm season. Food to satisfy hunger, and warmth to protect against cold are, of course, physically necessary material resources, but they are also channels of symbolic, ritual, and social communication. Caregiving of frail elders is most closely related to alms offerings or sacrifice, focused on specific age groups: the very young and the very old. One purpose of alms is to promote the satisfactory outcome of a wish or goal. As earlier noted, alms should be given to small children on Fridays in order to avoid misfortune or compensate for a misdeed (Rasmussen 2001a). Other situations require that alms be given to impoverished and/or frail elders in order to ensure their al baraka (blessing) protection from dangers such as thieves and lightning storms. Children also receive food in many ritual contexts, defined as "alms offerings" (takote), also denoting the commemorative mortuary feasts held at intervals following deaths.

As they weaken physically, elders are ideally cared for, and receive, but also give, alms - both before death, in gradual pre-inheritance gifts, and following death, in the Islamic scholars' distribution of their remaining uninherited property to the poor. Many Tuareg, upon my 
inquiring what most comes to mind when thinking of old age, immediately and emphatically exclaimed, "Takote!" Both forms of caregiving and almsgiving - to the very old and the very young-are necessary, in local viewpoints, in order for the givers to obtain Islamic blessing or benediction.

Like frail elders, Tuareg babies and very young children are considered closer to the pre-Islamic spirit world, thus approximating Beng babies' "arrival" from the afterlife (Gottleib 2004). There are also hints that Tuareg frail elders occupy special, respected status as pre-ancestral, as mediators between humans and ancestors. But here, in contrast to the Beng, these connections are less explicit or direct; for mainstream ("official" Qur'anic) Islam discourages too-overt focus on the ancestors as distracting from the monolithic God, Allah. Also, the Islamic paradise is qualitatively distinct from other (pre-Islamic) spiritual abodes: essuf, the wild or solitude; idebni, the graves of recently deceased persons; and ibedni, ruins of more genealogically remote people of the past.

Frail elders' secluded residence partly reflects, I argue, their position partially in paradise and partially in the wild and the other related spaces, thereby reflecting Tuareg dilemmas over Islamic and pre-Islamic cosmologies and rituals surrounding the life course. Many emphasize the need to sever a newborn's ties to the spirit world, fearing that spirits may pull him or her back into their realm of essuf. To prevent this fate, a week-old infant's hair is shaved off on the nameday ceremony. The new mother and her infant remain secluded to protect against these jealous spirits (Rasmussen 1995, 1997), only emerging at the baby's nameday held one week following the birth. The newborn baby, like the frail elder and the recently deceased, is not addressed or referred to by a personal name, but is called "stranger" or "guest" (amagar, fem. tamagart) until the nameday. At weaning age, some mothers style their firstborn male children's hair into a small tuft on the top of the head to enable the Prophet to pull him up into Paradise (notably, not to enable the Kel Essuf to pull him into essuf). This idea is the Islamic interpretation of the threat of child mortality. The small boy must now embark on the path to becoming a mature Muslim male.

For both very young and very old, therefore, thresholds and crossroads are ritually significant. Some birth defects, such as mental disabilities, are widely attributed to a mother having paused in a doorframe while holding her baby momentarily in it. Both very young and very old persons are liminal, standing at the interstices of life and death, and have uncertain, disputed and ambiguous ties to the living and other worlds. In some contexts, both age groups experience literal, as well as symbolic spatial seclusion and similar linguistic marking and tropes.

What are the meanings of these approximately (though not exactly equivalent) symmetrical images and practices surrounding the very young and the very old? How do these beliefs affect caregiving of frail elders in their apparent solitude of residential seclusion, and how do socio-economic predicaments - longstanding, recent, and current-of many Tuareg households interact with these spiritual predicaments? In some respects, these spatial, ritual-symbolic, and social patterns of frail Tuareg elders living "a little to one side" suggest pre-emptive social death - but I never encountered practices Glascock (2009) has termed "death-hastening" as a conscious, overt intention in this seclusion. Adults do appear, however, not to wish to see frail elders. Yet death denial occurs in efforts to preserve living-deceased communication in beliefs, practices, and stories concerning living-dead interaction through almsgiving and other interactions between graves, ancestors, and spirits, as these practices are interconnected. Although there are some hints of "social death" in the spatial and caregiving arrangements for Tuareg frail elders, there are also counter-forces here: in the complementarity and parallels between cosmology and ritual surrounding babies, very young children, and "old/old" frail elders. But Tuareg never expressed an idea of a circular "return" to infantile dependency upon advanced frail old age. Although elders and very young children and babies are all similarly believed to be closer to the spirit world, in other respects, they are not treated as equivalent, in every context.

As Cohen (1998), Kaufman (1986), and Vatuk (1980, 1990) point out, we need to consider the "becoming" as well as the "being" aspects of old/old age. We also need to detach aging from its solely literal frame, not to deny its very real effects, but to understand the cultural means of coping with them (Rasmussen 1997). To some extent, being frail and old/old becomes a source of positive meaning and empowerment in seclusion under children's watch, (or are these child caregivers under frail elders' watch?). Inside secluded space, the mutual gaze and reciprocal voices between these alternate generations collapse living and dying times and spaces.

Relevant here are the changing meanings of crossroads, interstices, and thresholds in a play of power and symbolism, as well as personal sentiments. As Stoller and Coombs (1994) have pointed out, crossroads in many African societies and cosmologies signify danger, but also 
opportunity, and a kind of transformative, indeterminate, and suspended identity. Liminal thresholds, entries and exits, and crossroads thus suggest mediation and transition, and offer possibilities of re-inventing the person in ways that empower the person spiritually, if not physically or socially. For example, on the eve of the official nameday, babies are carried by elderly female relatives around the mother's tent, though not through its doorframe. At weddings, on the final evening, the bride enters the tent through the front door, rather than through a side flap in the tent as on previous evenings in the week-long wedding. Smiths accompanying the bride to the nuptial tent enter through its left side. Graves and tombs are located well outside, but on roads connecting villages and camps. The place where a person died is covered with tree-branches, and its ground is considered sacred or taboo, al hima (Ag Solimane 1999). Some, but not all cases of placement in outside but connecting nonstandard spaces convey pollution. Entrances, exits, and liminal times, spaces, and actions in ritual time and space ritually mark some dangerous state, situating persons in ambiguity, but not always abjection.

Thus, in one respect, the Tuareg data approximate Cohen's findings (1998) in urban India, in the sense that there are more nuanced meanings involved in the placement of dying spaces than marginality or abjection. But in another respect, the Tuareg case markedly differs from the India case in its social consequences and implications. In India, according to Cohen, although this space (of the frail and dying elder) is not quite part of the household, nonetheless, the old person on the threshold is the first person one would encounter in visiting. In India, the charpoy bed-platform is "simultaneously that of confinement and repose, restriction and respect" (Cohen 1998:182).

In other respects, there are contrasts between Tuareg spaces and Indian spaces. As observed, frail, disabled, and/or dying Tuareg elders tend to be lodged away from public scrutiny and greetings, and do not often receive many adult visitors. The secluded Tuareg old person is often hidden from view. From whom and why? In the case of the elderly local chief of that community early in my research who was variously described as suffering from dementia (takhal) or from a disabling foot ailment, I never saw him, rather, I saw only his still active son, who had taken over his duties. Similarly, after the (now deceased) traditional anestafidet (leader) of the Kel Ewey confederation in Agadez became blind in his advanced age, no one visited him; he and his wife always sat alone inside their home.
Yet the secluded frail elder's powers of evoking memory should not be underestimated. Children absorb much oral history, for television is not yet a feature of rural Saharan communities. Moreover, small children acting as intermediaries and caregivers can listen and observe fragility, thereby conferring some empowerment through empathy and communicating wishes indirectly through messages. Sidi's dilapidated and nearly-abandoned compound, though it mirrored the frail elder's physical state, also evoked memories of contrasts there some fifteen years earlier, when it had been a center of lively sociability and storytelling. Although this compound now metaphorically represented the old man's bodily fragility, it also prompted people to remember a happier time of his past "prime."

When my research assistants and hosts (now a married couple) had planned to marry years before, the soon-tobe- groom was constructing this compound nextdoor to that of his father Sidi and mother Tanou. Both were at that time considered imgharen with their children grown and marriageable or married, but still vigorous and active. Sidi had been an accomplished Islamic scholar, in a clan of prominent marabouts closely related to the local chiefly family. In his youth, he had gone caravan trading. He owned several oasis gardens and a few livestock, though the latter were diminished from droughts. The older couple had enthusiastically recounted folk tales and legends to me, several with themes of elder/children/ alms relationships. In one tale, small children visit and give offerings to the tombs of their patrilineal ancestors. Sidi and his wife explained this tale as reminding youths to visit relatives on a Muslim holiday (Rasmussen 1997). Their voices in the foregoing narratives, though part of the past, continue to "echo" in current cultural knowledge and practice in contexts of ritual, if not secular power.

Many Tuareg explained that "spirits fill places that were once full of people and are now deserted and full of nostalgia (another meaning of essuf)," for example, abandoned campsites, sacrificial terrains, and razed markets. There are efforts not to upset these spirits in such practices as almsgiving to obtain al baraka blessing. Essuf is not in every respect a negative place, but is also a place of creativity, for example, the best poets are said to compose their verses in the wild, and herbalists gather their tree medicines there. Spirituality is therefore relevant, indeed fundamental, to the meanings of frail elders' seclusion and their consequences in caregiving. 


\section{AtTitudes toward Frail Old Age In RELATION TO HOUSEHOLD DYNAMICS}

Also relevant here are the economics and politics of caregiving. What does the current Tuareg household predicament imply about household "exclusion" in advanced aging? Albert and Cattell (1994) have pointed out that modernization and globalization have had enormous impacts in Africa and elsewhere. In Niger and Mali, economies have declined in recent years, poverty has increased, and daily struggles for survival have intensified. Unemployment, monetarization, ecological disasters, and wars have diminished livestock, and propelled many young Tuareg men into labor migration and political exile abroad. ${ }^{6}$ Many young men skip the traditional male rite of passage and socialization: the now-disrupted trading caravans for salt and dates across the Sahara under the authority of elderly male relatives, who conduct tests transforming youths into men (Claudot-Hawad 2002). These processes have consequences for frail elders' authority patterns and intergenerational relationships.

Yet elders are not excluded from family support systems. There remains great emphasis upon outward public reserve toward, and on the part of, still-vigorous older parents whose children are of marriageable age or recently married, and their own dignity (imojagh), and others' strict respect/ reserve/distance/avoidance (takarakit) toward them are necessary for adapting to household transformations and transitions. Following children's marriages, one should increase one's time devoted to prayer and Islamic rituals, for example, in the mortuary alms feasts and in chanting liturgical music, and one should withdraw from more "secular" or "frivolous" festivals, especially in communities where Islamic scholars and icherifan clans claiming descent from the Prophet are numerous and influential. These orientations ideally reinforce still-vigorous elders' important authority positions as household heads: as decision-makers (for example, where to move a nomadic camp), as namers of children and grandchildren, and as prominent participants in rites of passage, and healing specialists (Rasmussen 2006).

Married persons practice a reserve or "shame" or "avoidance" (takarakit) relationship toward their parentsin-law involving name teknonymy and refraining from eating in their presence. New bridegrooms must wear the men's faceveil-turban high on the face (over the nose and mouth) before the mother-in-law, bring back food goods and cash from oasis garden produce, trading and labor migration products and cash for their parents-in-law, and must refrain from looking into the latters' grain storehouse.

By contrast, confirming Radcliffe-Brown's classic observations long ago, as in many other cultural settings, playful joking relationships are frequently practiced in public betweenalternategenerations:namely, grandparents and grandchildren. Grandmothers often mock breastfeed their daughters' babies, and grandfathers-even chiefs and marabouts - often allow young children to play with their face-veil, normally taboo to other persons, as this is a symbol of adult male gender modesty and respect.

Household residential changes, domestic subsistence patterns, and kin relationships also powerfully affect later caregiving of frail elders. Many of these practices respond to wider changes outside the household; in the past, related to pastoral nomadism, and currently related to global pressures, namely (predominantly young men's) labor migration and kin relationships (especially fatherson and parents-in-law and children-in-law) impacted by this, state and NGO-engineered pressures on Tuareg nomads to sedentarize, droughts, and sporadic armed conflicts between Tuareg dissidents and national armies in the Saharan region. In semi-nomadic and sedentarized communities, occupations are now diverse within a single household, regardless of the family's social stratum origin. One child may become a gardener, another a herder and caravanner, another may depart on labor migration, and yet another may operate a market stall or small boutique in a town. These patterns cause lengthier, less predictable separations than the older seasonal fission and fusion of households in nomadism and caravanning.

Many youths, returned from travels, but unemployed and unable to raise bridewealth, marry, or reintegrate into Tuareg society, form a post-Tuareg rebellion wave of an age cohort known as ichumaren (denoting approximately "the unemployed"). Many elders lament that "reserve (respect) has been abandoned," and relate stories of children refusing arranged marriages with close cousins and/or endogamously within the same social stratum, discarding the men's face-veil, and neglecting Islamic prayers and other rituals (Boilley 1999; Rasmussen 2000a, 2000b).

As a result, intergenerational and kinship roles are becoming more fragmented. This trend is double-edged in its consequences. Youthful men, once dependent upon the mother-in-laws' approval for establishing independent married households with their wives, now enjoy greater freedom if they are able to successfully benefit from the increasingly monetarized economy beyond subsistence 
work for parents and parents-in-law. For those youths who are unemployed, by contrast, elders' authority may be less contested. But even these youths still hold many "cards" since they cannot support elders so generously in late life, and elders know this.

In rural, more nomadic households, many older women and men still assert much control over their children and children-in-law. But these sources of authority are dependent upon the older nomadic livestock economy, in which inheritance of herds acted as a powerful source of leverage over youths; and this economy is now threatened by droughts and wars. In sedentarized oases and towns, residents are moving toward farming, labor migration, and cash-based markets. Caravan trade goods-traditionally bartered-are no longer sufficient to support the household and elderly parents.

Wider political events are also relevant here, though not the primary cause of Sidi's and others' residential arrangements. Sidi's predicament is typical in many respects, but atypical in one respect. Traumatic regional violence and dispersal of refugees may have accelerated his physical and mental decline, and also undermined, rather than reinforced, his potential to continue some aspects of the ideal authority role over the heretofore seminomadic, seasonally unified household. In the late 1990's, he and his family were forced to evacuate with other refugees from an attack by government army soldiers, who accused local residents (falsely or accurately, I do not know) of supporting and sheltering dissident rebel fighters. This catastrophe undoubtedly traumatized Sidi further, whether he had been frail before that event or not, though he did not mention it to me himself, Friends and assistants away from his presence related sorrowfully, "We had to place our old and sick people on donkeys and camels...until we arrived safely at a distant oasis higher up in the mountains Many people died. One woman spent two days in hiding with her children without food." My long-term hosts in that region joined refugees in flight who temporarily resettled in that mountain oasis, where they had to start new gardens, occupy smaller residential spaces, or camp out in the dried riverbed and rely on local assistance for food and water. Upon return to their village after mediation of that conflict in Algiers, they found that some soldiers had stolen medicines, grains, livestock, and household valuables such as women's jewelry.

There were also gardening land shortages from these demographic upheavals. So Sidi's son (my assistant/host) had decided to farm back in the mountain village where he had fled, where his wife's parents still resided. He left his aging father inside that compound back in his village, since his sisters and their households were located just adjacent to it. That is how I found him.

How far did the local religious cosmology and how far did the local political-economic trauma each contribute to the seclusion and youthful caregiving of frail elders? It is tempting to attribute much causal connection to the traumatic violence and their aftermath. Yet it should be noted that, except for the refugee flight and return, Sidi's caregiving situation was not new, aberrant, or atypical; for as already observed, during peaceful times, as well, frail elders are almost always housed in removed spaces; recall that even the former (now-deceased) local chief and the anestafidet were earlier in my research, during more peaceful and prosperous times. Sidi would have occupied such as place "a little to one side" in the distant oasis, as well, had he gone there, but the compound of his son and his wife there was considerably smaller; thus it made sense to house him back in their village of origin near his daughters. Indeed mobility and upheavals are not entirely novel; for many Tuareg have longstanding experience of travel in nomadism and caravanning, and suffering from battles in raids. Thus these wider pressures affect, but do not overturn completely, local strategies of caregiving.

Even prior to these far-reaching recent upheavals, moreover, even still-vigorous elders' authority was never uncontested. Some youths, for example, opposed parents' choices of a marriage partner; others accepted this as a first marriage, but later divorced and re-married according to their own choice. Others departed on travel, never to return for years. There is not, and never has been, a guarantee of late-life unified household, support, companionship, or caregiving. Many gossip about (supposedly) rare cases of dire neglect of frail elders, for example, a marabout related disapprovingly how "one invalid elderly parent wanted water, but his family denied him sufficient quantities of this, and they will surely not go to paradise!" Perhaps adults rely on young children as caregivers in part because they can most easily delegate this responsibility to them, and also because alternate generations need not conceal shameful conditions of both very young and very old (i.e., of weakness, illness, dirt). Children are also sent to look in on sick persons.

These practices have to do with the important Tuareg value called takarakit, which denotes reserve and shame, in addition to respect. Relevant here are longstanding tensions, contradictions, and dilemmas surrounding youth-elder and intergenerational relationships, both past and present, and their modifications. The ideals of reserve 
and dignity can mask a tension between what it means to be an elder as a leader (amghar) and simultaneously be a spouse, (if not widowed), grandparent, parent, affine, and pre-ancestor. Still-vigorous elders can and do hold these roles simultaneously, but they must mask this simultaneity in public: they must, in effect, maintain a distance in order to retain authority, but remain visible to exercise that authority. Later, upon decline and senescence, there is the need to conceal elders', particularly chiefs' and Islamic scholars', waning physical strength and official authority. For if this is revealed too openly, their al baraka risks being doubted. These frail elders need to be kept separate from still-fertile young childbearing women. Small children are ideal buffers since they, too, occupy liminal status. Thus socioeconomic and political factors, cosmology, and ritual are all powerful in shaping the interior space and psyche of frail elders' predicament.

\section{Interior Psychic Border-Crossing}

Frail elders stand, as it were, at the confluence of mutually-incompatible physical, cosmological, ritual and sociopolitical powers. In this, their spatial separateness and social withdrawal convey their simultaneous disengagement, frailty, but also their newly active spirituality and alternative powers. They are both mediators and bystanders, but risk becoming neither as abject "anomalies."

Notwithstanding these dangers, in withdrawal from worldly authority, some active aging may nonetheless take place indirectly. Most old/old persons continue some light handiwork - for example, men often make ropes for household and travel uses. Frail elders who are comfortable enough to speak relate tales and reminiscences to children, thereby commenting on local mythico-history. A few remain very alert, and sometimes reveal important healing knowledge (Rasmussen 2006). The peripheral residential space thus bears some resemblance to a "time-capsule" and to the Australian Aboriginal "dreamtime" as a time/ space where past and present meet. The close relationship between children, elders, spirits, ancestors, graves, and the afterlife involves a kind of "beforelife" or becoming, perhaps a life review as well. Sometimes, ancestors in graves and spirits near them are believed to greet people on the road or even ask for belongings, especially from children. Children are also believed to often stumble upon Kel Essuf spirits playing miniature tende mortar-drums in empty riverbeds. There is a tale about spirits stealing babies, upon mistaking them for goat-hide waterbags.

Moreover, the spatial symbolism of frail elders' seclusion recalls, but also diverges from, the symbolism of Tuareg smith/artisans' marginality. Both figures are mediators, though smith/artisans are social mediators. Smith/artisans act apart from, but also centrally as go-betweens for other Tuareg, lack dignity and reserve, and convert natural into cultural substances. Frail elders nearing death are, their physical seclusion notwithstanding, also mediators, albeit in a different sense: the old/old convert cultural persons into spiritual beings (living and deceased) - for example, in their participating in naming of children and in telling histories to and about small children portraying ideal values of heroes' resistance to oppression, protection of life, and generosity between the generations. In feeding the frail elder, small children in effect are giving them alms the reciprocal counterpart of many other occasions when adults give alms to small children.

\section{CONCLUSIONS}

The space of the frail old/old is not shrinking. Rather, it has always been peripheral and central at once. This article reveals more nuanced and dynamic multigenerational relationships, semiotics of space, ritual and social practices on advanced aging. The essay also challenges some representations of frail, even dying elders as entirely disengaged or passive. The Tuareg data indicates that, although there occur some physical and politicaleconomic disengagement and withdrawal from official political authority contexts, there also occurs, despite pain and suffering, alternative empowerment of the personnot always realized by everyone, but available as cultural possibilities.

Secluded space can isolate elders from family and production, as in the peripheral hospices in Western Europe, the United States, and urban India. In many "occidental" societies, segregated physical space and built form can disempower persons and erase memory. The Tuareg data suggests that elders' association with both ancestors and children in a space of creativity forges a subtle power that, when not radically disrupted, confers meaning to declining physical and social personhood.

\section{Notes}

${ }^{1}$ Most Tuareg remain predominantly rural, but many have been pressured toward sedentarization and migration to towns, first by French colonial administrations and later by some independent central state governments and aid programs.

${ }^{2}$ In the past, social stratum affiliation was inherited, based on descent. Aristocatic imajeghen controlled most large livestock, weapons and the caravan trade, tended to be more nomadic, 
and collected tributes and rent from more sedentarized farming and other peoples of varying client and servile status (ighawalen and $i k l a n)$. Iklan were owned, often war captives, and were liberated on independence at mid-century. Tributaries, imghad, some former nobles defeated in battle, raided and traded for imajeghen in exchange for military protection, usufruct rights, and part of the booty in war. Inaden, smith/artisans, manufactured tools, jewelry, recited oral histories, officiated at rites of passage, and acted as important go-betweens for their aristocratic patron families. Islamic scholars (ineslemen, popularly called "marabouts") interpreted the Qur'an, and continue this role as well as divination, counseling, and medicoritual healing.

${ }^{3}$ There are some challenges to these gendered arrangements in groups more influenced by Qur'anic law, Islamic scholars, and Islamist-reformist movements, as well as in sedentarized oases and large towns more influenced by nation-state family code laws and other ethnic groups.

${ }^{4}$ Many Tuareg groups now practice bilateral or "double" descent, combining to various degrees, matrilineal and patrilineal legal systems of inheritance and secession. But in most groups, most women inherit property through endowments called akh ihuderan or "living milk" intended to compensate them for the male bias of Qur'anic inheritance in which two-thirds of property go to male heirs and one-third go to female heirs. Most women go about unveiled, may travel and visit freely and receive unrelated male visitors, even after marriage, and may initiate divorce.

${ }^{5}$ The post-colonial Tuareg armed rebellions began in 1963 in the northern Kidal region of Mali over food distribution and taxation, and have recurred in both countries sporadically between 1990-1996, in 2007 in the northern Arlit and Iferouan regions of Niger over uranium mining contracts, and most recently, in January 2012 in northern Mali. Until recently, the northern and more nomadic regions of these countries were marginalized politically and economically. Peace accords promised semi-autonomy, greater economic aid for these regions, as well as greater integration of Tuareg into the national armies, higher education, and jobs in the new infrastructures. But national budgets are limited, and control over policies and events in the peripheral border regions has been uncertain.

${ }^{6}$ There have been a series of droughts: in 1913, 1969-1976, 1984, and more recently, also locust invasions around 2005, as well as resurgences of the Tuareg rebellion against the central state governments of Niger and Mali and national unemployment problems throughout these countries, as well, which have propelled refugee flight and exile out of Tuareg regions. Most recently, the 2011 war in Libya caused an influx of refugees into some Tuareg regions, particularly Niger.

\section{References}

Ag Solimane, Alhassane

1999 Bons et mauvais presages: Croyances, Coutumes et Superstitions dans la Society Touaregue. Paris: L'Harmattan. Albert, S.M. and M.G. Cattell

1994 Old Age in Global Perspective : Cross-Cultural and Cross-National Views. New York : G.K. Hall.
Bernus, Edmond

1981 Touaregs Nigeriens: Unite Culturelle d'un People Pasteur. Paris: ORSTOM.

Boilley, Pierre

1999 Les Touaregs Kel Adagh. Paris: Karthala.

ouman, AnnMarie

2003 Benefits of Belonging. Utrecht: University Ph.D. dissertation.

Bourgeot, Andre

1994 Revoltes et rebellions en pays touareg. Afrique contemporaine: Etudes 170, no. 2: 3-19.

Claudot-Hawad, Helene

1993 Touareg: Portrait en fragments. Aix-en-Provence: Edisud.

2002 Voyager d'un point de vue nomade.

Cohen, Lawrence

1998 No Aging in India: Alzheimer's, the Bad Family, and other Modern Things. Berkeley: University of California Press.

Cumming, Elaine and William F. Henry

1961 Growing Old: The Process of Disengagement. New York: Basic Books.

Dayak, Mano

1992 Touareg, La Tragedie. Paris: Editions Jean-Claude Lattes.

Douglas, Mary

1966 Purity and Danger. London: Routledge and Kegan Paul. Glascock, Anthony P.

2009 When Is Killing Acceptable: The Moral Dilemma Surrounding Assisted Suicide in America and Other Societies. In The Cultural Context of Aging: Worldwide Perspectives, Jay Sokolovsky, ed. Pp.77-93. Westport, CT: Bergin \& Garvey Press.

Goody, Jack

1958 The Developmental Cycle of Domestic Groups. Cambridge: Cambridge University Press.

Gutmann, David

1987 Reclaimed Powers: men and Women in Later Life. Evanton: Northwestern University Press.

Kaufman, Sharon R.

1986 The Ageless Self: Sources of Meaning in Late Life. Madison: University of Wisconsin Press.

Keenan, Jeremy

2003 The End of the Matriline? The Changing Roles of Women and Descent amongst the Algerian Tuareg. The Journal of North African Studies 8 (3-4): 121-162.

Lamb, Sarah

2000 White Saris and Sweet Mangoes: Aging, Gender, and Body in North India. Berkeley: University of California Press.

Nicolaisen, Ida and Johannes Nicolaisen

1997 The Pastoral Tuareg. Copenhagen: Rhodos.

Oxby, Clare

1990 The Living Milk Runs Dry: The Decline of a Form of Joint-Ownership and Matrilineal Inheritance among the Tuareg (Niger). In Property, Poverty and People. P.T.W. Baxter and Richard Hogg, eds. Pp. 222-228. Manchester: Manchester University Press.

Radcliffe-Brown, A.R.

1938 Taboo. The Frazer Lectures. Cambridge Uhniversity Press. 
Rasmussen, Susan

1995 Spirit Possession and Personhood among the Kel Ewey Tuareg. Cambridge: Cambridge University Press.

1997 The Poetics and Politics of Tuareg Aging: Life Course and Personal Destiny in Niger. DeKalb: Northern Illinois University Press.

2000a Between Several Worlds: Images of Youth anhd Age in Tuareg Popular Performances. Anthropological Quarterly 73(3): 133-145.

2000b Alms, Elders, and Ancestors: The Spirit of the Gift among the Tuareg. Ethnology 39(1): 15-38.

2001a Healing in Community: Medicine, Contested Terrains, and Cultural Encounters among the Tuareg. Westport, CT: Greenwood/Bergin \& Garvey.

2001b Wedding of Calm and Wedding of Noise: Aging Performed and Aging Misquoted in Tuareg Rites of Passage. Journal of Anthropological Research (57):277-303.

2006 Those Who Touch: Tuareg Medicine Women in Anthropological Perspective. DeKalb, IL: Northern Illinois University Press.

Rosaldo, Renato

1989 Culture and Truth. Boston: Beacon Press.

Sokolovsky, Jay, ed.

2009 The Cultural Context of Aging. Westport, Ct.: Bergin \& Garvey/Greenwood.

Stoller, Paul and Rosemary Coombs

1994 X Marks the Spot: The Ambiguities of African Trading in the Commerce of the Black Public Sphere. Public Culture (7):249-274.

Vatuk, Sylvia

1980 Withdrawal and Disengagement as a Cultural Response to Aging in India. In Aging in Culture and Society. Christine Fry, ed. Pp. 126-148. New York: Praeger.

1990 To Be a Burden on Others:" Dependency Anxiety among the Elderly in India. In Divine Passions: The Social Construction of Emotion in India, Owen Lynch, ed. Pp. 6488. Berkeley: University of California Press. 